\title{
Effect of salted fish waste and cow manure on NPK availability and uptake of lowland rice on peat soil in Pelalawan Riau
}

\author{
Dian Syafitri Ompusunggu, Benito Heru Purwanto*, Cahyo Wulandari, and Sri Nuryani Hidayah Utami \\ Department of Soil Science, Faculty of Agriculture Universitas Gadjah Mada \\ Jln. Flora no. 1, Bulaksumur, Sleman, Yogyakarta 55281, Indonesia \\ *Corresponding author: benito@ugm.ac.id
}

Received: 04 ${ }^{\text {th }}$ July 2019; Revised: 19 ${ }^{\text {th }}$ November 2019; Accepted: $21^{\text {st }}$ November 2019

\section{Keywords:}

Cow manure, peat soil, rice, salted fish waste

\begin{abstract}
The low yield of rice in thick peat can be overcome by provisioning complete nutrients. Various efforts have been made to increase the productivity of Indonesian peatlands, one of which is by adding salted fish waste and cow manure. This research was carried out on a plastic house scale from October 2017 to January 15, 2018, in Pelalawan District, Pelalawan Regency, Riau. This research was arranged in a Completely Randomized Design (CRD), consisting of eight treatments, namely LO = Control, L1 $=1.5$ ton.ha ${ }^{-1}$ of fish waste, $\mathrm{L} 2=2.25$ ton. ha ${ }^{-1}$ of fish waste, $\mathrm{L} 3=7$ ton. ha ${ }^{-1}$ of cow manure, $L 4=15$ ton.ha ${ }^{-1}$ of cow manure, $\mathrm{L} 5=1.5$ ton. ha ${ }^{-1}$ of fish waste +7 ton. ha ${ }^{-1}$ of cow manure, $L 6=1.5$ ton. ha ${ }^{-1}$ of fish waste +15 ton.ha ${ }^{-1}$ of cow manure, $\mathrm{L} 7=2.25$ ton.ha ${ }^{-1}$ of fish waste +7 ton.ha ${ }^{-1}$ of cow manure, and $L 8=2.25$ ton.ha ${ }^{-1}$ of fish waste +15 ton.ha ${ }^{-1}$ of cow manure. The results showed that the application of cow manure and salted fish waste could increase soil pH, total NPK, and NPK uptake. The application of 2.25 ton.ha ${ }^{-1}$ of fish waste and 15 ton.ha ${ }^{-1}$ of cow manure resulted the best results in soil pH, total NPK, and NPK uptake, therefore it is recommended for the cultivation of lowland rice on peat soil.
\end{abstract}

\section{INTRODUCTION}

Peat soil is marginal soil for agriculture due to its low fertility. The physical constraints of peat soil include nutrients with low bulk, low soil support leading to subsidence, and irreversible drainage (Agus and Subiksa, 2008), while the chemical constraints include low $\mathrm{pH}$, low availability of macro $(\mathrm{K}, \mathrm{Ca}, \mathrm{Mg}, \mathrm{P})$ and micronutrients ( $\mathrm{Cu}, \mathrm{Zn}, \mathrm{Mn}$, and $\mathrm{Bo})$, toxic organic content, and low base saturation (Najiyati et al., 2005). However, the limited availability of mineral land leads to the unavoidable agricultural expansion to peatlands (Salsi, 2011).

Lowland rice cultivation is continuously attempted to meet the food demands, but the cultivation on peat soil is faced with various physical-chemical constraints mentioned above. Rice field is a suitable choice for managing peat soil. Rice cultivation will reduce acidity of the peat soils in reduced and ensure the pyrite in a stable condition. therefore there is no harmful effect on the plant (Limin, 2006). Thick peat ( $>1 \mathrm{~m}$ ) cannot be specifically utilized for rice cultivation since some of other contraints have not been solved. The cultivation of lowland rice cultivation on peat soil depends on the management in handling the physical and chemical constraints, toxic substances, and macro and microelement fertilization (Radjagukguk, 1997).

To improve the fertility of peat soil, ameliorants such as salted fish waste and cow manure need to be applied to increase the nutrient content of peat soil (Salsi, 2011). Manure is derived from cow dung functioning as soil enhancers and as nutrient suppliers including N, P and K. Salted fish waste has quality as a good fertilizer and has complete nutrients for plants (Ministry of Marine Affairs and Fisheries, 
2005). Fish waste in Riau province is abundantly available in a relatively cheap price because most of the population are fishermen. However, salted fish waste has a high $\mathrm{NaCl}$ content due to its manufacturing process. The content of $\mathrm{NaCl}$ can increase osmotic pressure and result in plant toxicity. Besides, the excessive $\mathrm{NaCl}$ can reduce water absorption and affect plant physiology. Salinity stress also increases the level of $\mathrm{Na}$ and $\mathrm{Cl}$ toxicity in cells, thereby limiting absorption of $\mathrm{K}$ (Munns and Tester, 2008). Therefore, salted fish waste must be applied at the right doses and at the right time, which in its application, it is better applied to plants in dry condition under sunlight and smoothed in order to reduce levels of $\mathrm{NaCl}$. This study aimed to determine the effect of salted fish waste and cow dung on the NPK availability and uptake of rice on peatlands in Pelalawan Regency, Riau.

\section{MATERIALS AND METHODS}

The research was conducted from October 2017 to January 15, 2018 in plastic houses in Pelalawan District, Pelalawan Regency, Riau Province. Laboratory analysis was carried out in the General Soil Laboratory, Laboratory of Chemistry and Soil Fertility, Kuningan Laboratory, Department of Soil Science, Faculty of Agriculture, Universitas Gadjah Mada, Yogyakarta. This research was arranged in a Completely Randomized Design (CRD) consisting of 8 treatments with 3 replications within each treatment. The treatments were $\mathrm{LO}=$ Control, $\mathrm{L} 1=1.5$ ton. ha ${ }^{-1}$ of fish waste, $\mathrm{L} 2=2.25$ ton.ha ${ }^{-1}$ of fish waste, $\mathrm{L} 3=7$ ton.ha- ${ }^{-1}$ of cow manure, L4 $=15$ ton.ha ${ }^{-1}$ of cow manure, $L 5=$ 1.5 ton. ha ${ }^{-1}$ of fish waste +7 ton.ha ${ }^{-1}$ of cow manure, L6 $=1.5$ ton.ha ${ }^{-1}$ of fish waste +15 ton.ha a $^{-1}$ of cow manure, $\mathrm{L} 7=2.25$ ton. ha ${ }^{-1}$ of fish waste +7 ton. ha ${ }^{-1}$ of cow manure, and $L 8=2.25$ ton. ha ${ }^{-1}$ of fish waste +15 ton.ha-1 of cow manure.

A pot with a height of $50 \mathrm{~cm}$ and a diameter of $40 \mathrm{~cm}$ was filled with $5 \mathrm{~kg}$ of peat soil and was added with salted fish waste and cow manure according to the treatment. The salted fish waste used in this study is salted fish whose quality has decreased greatly so that it cannot be consumed anymore and is sold at a relatively cheap price, usually used to mix animal feed. Salted fish waste was obtained from traditional market waste, and the type of fish used is anchovy. Soil samples were taken before the administration of salted fish waste and cow manure for initial soil analysis. Before the administration, the salted fish waste was dried and smoothed to pass the 5-mm sieve. Mixing was carried out in a plastic bag by flipping it back and forth until it was mixed evenly, then the peat was put back into the pot that had been labeled according to the treatment and added with water until it reached the field capacity of water content and was incubated for 10 days. Soil samples were taken for analysis after the incubation.

Variables observed were soil chemical properties and plant growth components. The variables of soil chemical properties observed included soil $\mathrm{pH} \mathrm{H}_{2} \mathrm{O}$ by $\mathrm{pH}$ meter method, soil organic $\mathrm{C}$ content by combustion method, CEC by shaking method with $1 \mathrm{~N} \mathrm{NH}_{4} \mathrm{OAc} \mathrm{cmol}^{(+)} \cdot \mathrm{kg}^{-1}$, total $\mathrm{N}$ by Kjeldahl method $(\%)$, available $\mathrm{P}$ by Bray method (ppm), total $\mathrm{K}(\%)$,

Table 1. Chemical characteristics of cow manure and salted fish waste

\begin{tabular}{llcc}
\hline Variables & Unit & \multicolumn{2}{c}{ Cow manure Salted fish waste } \\
\hline $\mathrm{pH} \mathrm{H} \mathrm{H}_{2} \mathrm{O}$ & - & 7.0 & 8.2 \\
$\mathrm{EC}$ & $\mathrm{dS} . \mathrm{m}^{-1}$ & 4.39 & 3.58 \\
$\mathrm{C}-$ Organik & $\%$ & 34.0 & 42.88 \\
$\mathrm{~N}$ Total & $\%$ & 1.33 & 1.56 \\
$\mathrm{C} / \mathrm{N}$ Ratio & $\%$ & 25.56 & 27.48 \\
P-Available & $\mathrm{mg} \cdot \mathrm{kg}^{-1}$ & 0.16 & - \\
Total P & $\%$ & - & 1.28 \\
Total K & $\%$ & 0.60 & 0.56 \\
Total Ca & $\%$ & 2.9 & 0.80 \\
Total $\mathrm{Mg}$ & $\%$ & 0.7 & 0.32 \\
Total $\mathrm{Na}$ & $\%$ & - & 0.30 \\
\hline
\end{tabular}


total $\mathrm{Ca}(\%)$, total $\mathrm{Mg}(\%)$ and total $\mathrm{Na}(\%)$ by wet destruction method, and analysis of NPK levels and uptake in the shoot and roots. Soil sampling was done 10 days after the incubation and after the maximum vegetative harvest. The variables observed in this study were plant height, number of tillers, and fresh and dry weight of root and shoot when the plants were in the maximum vegetative stage. The results of the chemical properties analysis of salted fish waste and cow manure are presented in Table 1. Data were analyzed using analysis of variance (ANOVA) and tested using DMRT at $\alpha=5 \%$.

\section{RESULTS AND DISCUSSION}

\section{Chemical properties of peat soil}

Peatlands are transitional environments between terrestrial and aquatic ecosystems that provide essential hydrological, ecological and bio-geo-chemical functions (Krueger et al., 2015). This level of acidity on peat soil will be a significant limiting factor in the development of peat for agricultural purposes. This refers to several research results, which indicated that the acidity of peat soil is classified as very acidic. The acidity of peat soil is closely related to the content of organic acids, such as humic acid and fulvic acid (Miller and Donahue, 1990). Based on the Table 2, the total $\mathrm{N}$ content in peat soil generally shows a relatively high value of around 1.0 to $2.0 \%$, however, it is not available to plants due to high $\mathrm{C} / \mathrm{N}$ ratio. The $\mathrm{C} / \mathrm{N}$ ratio of peat soil is generally in the range of $20-45 \%$ and is increasing with the containers so that most of the $\mathrm{N}$ is still in organic form and is only available if it undergoes a change (Radjagukguk, 2000).

The available $P$ content in peat soil is very low, which is $0.4 \mathrm{ppm}$. The low availability of $P$ element is suspected due to the fact that the average $\mathrm{pH}$ in the research area is classified as acidic. $\mathrm{P}$ in soil dominantly comes from weathering rocks, while $P$ in peat soil comes from organic $P$ (Istomo 2006). The $\mathrm{K}$ content in peat soil is $0.23 \%$ (very low) because peat soils have low base saturation and ash content (Ratmini, 2012). The organic $C$ content in peat soils is classified as high (33.8). This result shows that the decomposition is not complete because the decomposition process is so low that $\mathrm{N}$ immobilization occurs. The change is said to be complete if the $\mathrm{C} / \mathrm{N}$ ratio is smaller than 20 (Radjagukguk, 1997). The high percentage of organic $C$ in peat soil is caused by the source of its constituent material, in which most of the dry materials in plants consist of organic matter. The content of soil organic matter is affected by soil depth, climate, soil texture and drainage.

Table 3 shows that the treatment given affects soil $\mathrm{pH}$, total $\mathrm{N}$, total $\mathrm{P}$, and total $\mathrm{K}$. The application of 15 ton. ha ${ }^{-1}$ of cow manure indicates the best results in affecting $\mathrm{pH}$ compared to control, which is 4.04 , despite the fact that the increase is still in the acidic category. This increase is possible due to the effect of cow manure application in the soil. The addition of large amount of cow manure into the soil can increase soil $\mathrm{pH}$, improve soil physical, chemical and biological properties, increase nutrients, and increase microbial activities, therefore, higher organic matter provided will increase the number of $\mathrm{K}, \mathrm{Ca}, \mathrm{Mg}$ and $\mathrm{Na}$ cations in the soil (Setyamidjadja, 1986). An increase in $\mathrm{pH}$ can occur due to the exchange of protons with added soil and organic matter and the exchange of protons between soil and fertilizer. The increase in $\mathrm{pH}$ by adding manure to acid soils can be explained in part by the exchange of protons between soil and additional fertilizers added (Wong et al., 1998). Consistent administration of

Table 2. Chemical characteristics of peat soil in Pelalawan Riau

\begin{tabular}{|c|c|c|c|}
\hline Variables & Unit & Value & Degree* \\
\hline $\mathrm{pH} \mathrm{H}{ }_{2} \mathrm{O}$ & - & 4.03 & acid \\
\hline Total N & $\%$ & 0.9 & very high \\
\hline Available-P & $\mathrm{mg} \cdot \mathrm{kg}^{-1}$ & 0.4 & very low \\
\hline Total K & $\%$ & 0.23 & very low \\
\hline Organic-C & $\%$ & 33.8 & high \\
\hline CEC & $\mathrm{Cmol}(-) \cdot \mathrm{kg}^{-1}$ & 116 & high \\
\hline C/N Ratio & $\%$ & 37.5 & very high \\
\hline
\end{tabular}

Remark : (*) Balittanah Criteria (2009) 
Table 3. Chemical characteristics of Pelalawan peat soil after incubation

\begin{tabular}{|c|c|c|c|c|}
\hline Treatment & $\mathrm{pH}$ & Total N (\%) & Total K (\%) & Total P (\%) \\
\hline Control & $4.04 \mathrm{c}$ & $0.90 \mathrm{c}$ & $3.38 \mathrm{~d}$ & $0.04 \mathrm{~d}$ \\
\hline 1.5 ton.ha ${ }^{-1}$ of fish waste & $4.16 \mathrm{bc}$ & $0.95 \mathrm{bc}$ & $9.90 \mathrm{bc}$ & $0.07 \mathrm{~cd}$ \\
\hline 2.25 ton.ha ${ }^{-1}$ of fish waste & $4.15 \mathrm{bc}$ & $0.98 \mathrm{bc}$ & $9.97 \mathrm{bc}$ & $0.08 \mathrm{bc}$ \\
\hline 7 ton.ha ${ }^{-1}$ of cow manure & $4.15 \mathrm{bc}$ & $1.22 \mathrm{ab}$ & $7.24 \mathrm{c}$ & $0.08 \mathrm{bc}$ \\
\hline 15 ton.ha ${ }^{-1}$ of cow manure & $4.44 \mathrm{a}$ & $1.24 \mathrm{ab}$ & $7.84 \mathrm{c}$ & $0.10 \mathrm{abc}$ \\
\hline 1.5 ton. ha $^{-1}$ of fish waste +7 ton.ha ${ }^{-1}$ of cow manure & $4.22 \mathrm{ab}$ & $1.21 \mathrm{ab}$ & $8.78 \mathrm{c}$ & $0.11 \mathrm{ab}$ \\
\hline 1.5 ton. ha ${ }^{-1}$ of fish waste +15 ton. ha ${ }^{-1}$ of cow manure & $4.22 \mathrm{ab}$ & $1.19 \mathrm{ab}$ & $12.7 \mathrm{ab}$ & $0.13 \mathrm{a}$ \\
\hline 2.25 ton.ha ${ }^{-1}$ of fish waste +7 ton.ha ${ }^{-1}$ of cow manure & $4.31 \mathrm{ab}$ & $1.20 \mathrm{ab}$ & $12.84 a b$ & $0.11 a b$ \\
\hline 2.25 ton.ha ${ }^{-1}$ of fish waste +15 ton. ha ${ }^{-1}$ of cow manure & $4.25 \mathrm{ab}$ & $1.27 \mathrm{a}$ & $14.10 \mathrm{a}$ & $0.10 \mathrm{abc}$ \\
\hline $\mathrm{CV}$ & 18.99 & 19.59 & 19.73 & 18.99 \\
\hline
\end{tabular}

Remark: Numbers followed by the same letters in one colomn are not significantly different according to DMRT at $\alpha=5 \%$.

Table 4. Analysis of crop height results and amount of rice tillers in peat soils in Pelalawan Riau

\begin{tabular}{|c|c|c|}
\hline Treatment & $\begin{array}{c}\text { Plant } \\
\text { height }(\mathrm{cm})\end{array}$ & $\begin{array}{l}\text { Number } \\
\text { of tillers }\end{array}$ \\
\hline Control & $94.6 \mathrm{~b}$ & $13.67 \mathrm{c}$ \\
\hline 1.5 ton.ha ${ }^{-1}$ of fish waste & 104.6 a & $15.33 \mathrm{bc}$ \\
\hline 2.25 ton.ha ${ }^{-1}$ of fish waste & $106.4 \mathrm{a}$ & $15.00 \mathrm{bc}$ \\
\hline 7 ton. ha ${ }^{-1}$ of cow manure & $104.5 \mathrm{a}$ & $16.00 \mathrm{bc}$ \\
\hline 15 ton. ha ${ }^{-1}$ of cow manure & 106.6 a & $16.67 \mathrm{~b}$ \\
\hline 1.5 ton.ha ${ }^{-1}$ of fish waste +7 ton.ha ${ }^{-1}$ of cow manure & $107.0 \mathrm{a}$ & $15.67 \mathrm{bc}$ \\
\hline 1.5 ton.ha ${ }^{-1}$ of fish waste +15 ton.ha ${ }^{-1}$ of cow manure & 106.3 a & $17.67 \mathrm{~b}$ \\
\hline 2.25 ton.ha ${ }^{-1}$ of fish waste +7 ton.ha $a^{-1}$ of cow manure & 105.6 a & $16.33 \mathrm{bc}$ \\
\hline 2.25 ton. ha ${ }^{-1}$ of fish waste +15 ton.ha ${ }^{-1}$ of cow manure & $113.3 \mathrm{a}$ & $20.67 \mathrm{a}$ \\
\hline
\end{tabular}

Remark: Numbers followed by the same letters in one colomn are not significantly different according to DMRT at $\alpha=5 \%$.

cow manure can increase soil pH (Mokolobate and Haynes, 2002).

The results of analysis of variance on total $\mathrm{N}$ in peat soil after incubation showed significant differences between treatments. The application of 2.25 ton.ha-1 of fish waste +15 ton.ha- ${ }^{-1}$ of cow manure treatment produced the highest total $\mathrm{N}$, while treatment $\mathrm{L} 1$ generated the lowest content of total $\mathrm{N}$. The increase in the content of total $\mathrm{N}$ seems to be in line with the treatment application. The higher the dose of fish waste and manure application, the higher the soil organic matter content. The results of analysis of variance on total $P$ of peat soil after incubation also indicated significant differences between treatments. The application of 1.5 ton.ha- ${ }^{-1}$ of fish waste +15 ton.ha ${ }^{-1}$ of cow manure treatment produced the highest total $P$, which was $0.13 \%$ compared to 1.5 ton. ha ${ }^{-1}$ of fish waste. The increase in total $\mathrm{P}$ also seems to be in line with the treatment application. This is because the application of higher cow manure can result in the reduction of $P$ fixation by acid cations in peat soil and can cause increasing availability in the soil (Surya and Suyono 2013). The form of organic $P$ in the soil mostly binds to calcium, iron, and ammonium. Of the three forms of bonding, the most important is organic $P$ that binds to calcium, especially in the form of mono and di-calcium phosphate, because this form is the most available ones for plants. The same results were also obtained for total $\mathrm{K}$ soil.

\section{Effect of treatment on the plant height and number of tillers of rice plants}

Table 4 explains that the treatment of salted fish waste and cow manure does not have a significant 


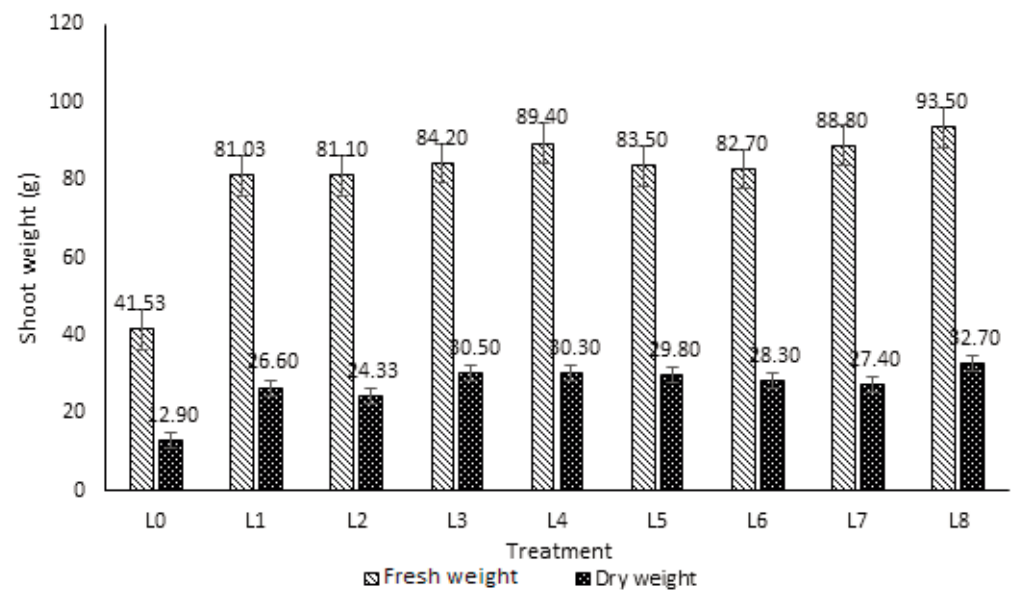

Figure 1. Fresh and dry weights of rice shoot

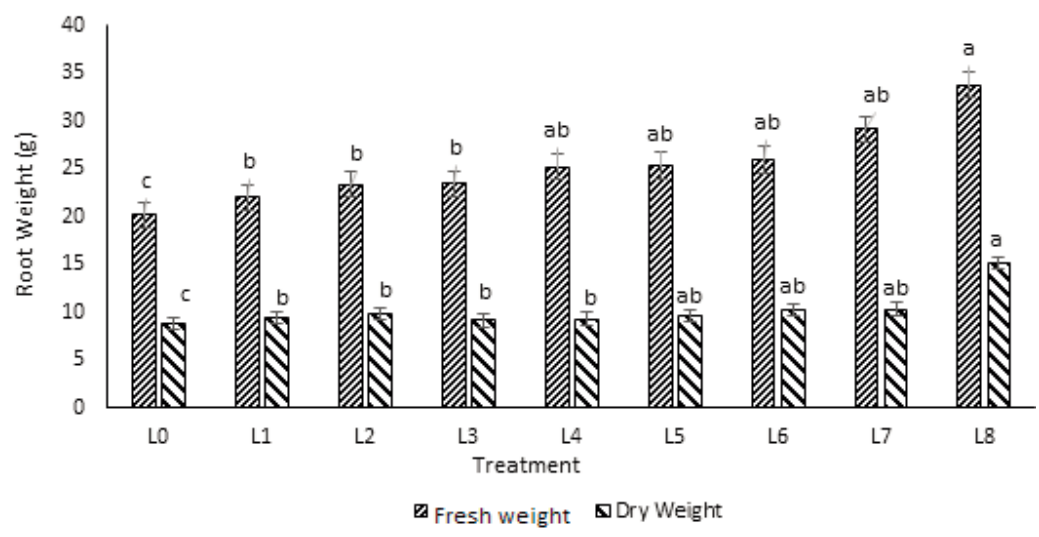

Figure 2. Fresh and dry weights of rice roots

effect on the plant height in the maximum vegetative phase (56 days after planting). The lowest plant height was found in plants with control treatment. Plant height is majorly related to plant genetic factors (Abduh and Annisa, 2016). The treatment given turned out to have an effect on the number of tillers of rice plants. The highest number of tillers was found in 2.25 ton.h $a^{-1}$ of fish waste +15 ton. ha ${ }^{-1}$ of cow manure treatment, while the lowest number of tillers was found in control treatment. This is because cow manure can add nutrients to the soil, improve soil physical, chemical and biological properties, and increase plant growth optimally. The application of cow manure affects the growth of tillers of rice. The higher the dose of cow manure applied, the higher the plant's ability to absorb nutrients (Setyamidjadja, 1986).

\section{Shoot dry and fresh weight of rice plants}

Figure 1 shows that of the pants treated with 2.25 ton. ha ${ }^{-1}$ of fish waste +15 ton. ha ${ }^{-1}$ of cow manure had the highest values of shoot fresh weight (93.50 g) and dry weight $(37.50 \mathrm{~g}$ ) so that the plant produced the highest weight difference ( $56 \mathrm{~g}$ ). Figure 2 shows that the highest fresh and dry weight of roots was found in the treatment of 2.25 ton. $^{-1} a^{-1}$ of fish waste +15 ton. ha ${ }^{-1}$ of cow manure. According to Salisbury and Ross (1995), fresh weight is the total weight of plants that shows the results of metabolic activity, while dry weight is the result of net accumulation of $\mathrm{CO}_{2}$ assimilation (Larcher, 1975). The availability of sufficient nutrients for plants will increase plant growth and development.

\section{Root dry and fresh weight of rice plants}

The results of the analysis showed that the treatment given had a significant effect on $\mathrm{N}$ uptake and $\mathrm{K}$ uptake, but had no effect on $\mathrm{P}$ uptake. Table 5 shows that the application of 2.25 ton. ha ${ }^{-1}$ of fish waste +15 ton.ha ${ }^{-1}$ of cow manure can increase $\mathrm{N}$ uptake compared to 1.5 ton.ha ${ }^{-1}$ and 2.25 ton.ha ${ }^{-1}$ 
Table 5. N, P, K uptake in plant shoot at the maximum vegetative phase (56 days after planting)

\begin{tabular}{|c|c|c|c|}
\hline \multirow{2}{*}{ Treatment } & \multicolumn{3}{|c|}{ plant shoot (mg per plant) } \\
\hline & $\mathrm{N}$ & $P$ & $\mathrm{~K}$ \\
\hline Control & $7.00 \mathrm{c}$ & $1.42 \mathrm{c}$ & $1.94 \mathrm{c}$ \\
\hline 1.5 ton. ha ${ }^{-1}$ of fish waste & $21.17 b$ & $3.99 a b$ & $5.85 a b$ \\
\hline 2.25 ton ha $^{-1}$ of fish waste & $23.87 b$ & $2.92 b$ & $4.14 b$ \\
\hline 7 ton.ha ${ }^{-1}$ of cow manure & $34.69 \mathrm{~b}$ & $5.49 \mathrm{a}$ & $6.71 \mathrm{a}$ \\
\hline 15 ton.ha-1 of cow manure & $39.35 \mathrm{~b}$ & $5.15 \mathrm{a}$ & 6.67 a \\
\hline 1.5 ton.ha ${ }^{-1}$ of fish waste +7 ton.ha ${ }^{-1}$ of cow manure & $45.47 \mathrm{~b}$ & $4.47 \mathrm{ab}$ & $4.77 \mathrm{~b}$ \\
\hline 1.5 ton.ha ${ }^{-1}$ of fish waste +15 ton.ha $^{-1}$ of cow manure & $61.54 \mathrm{ab}$ & $3.68 \mathrm{ab}$ & $5.09 a b$ \\
\hline 2.25 ton.ha ${ }^{-1}$ of fish waste +7 ton.ha-1 of cow manure & $68.35 \mathrm{ab}$ & $4.11 \mathrm{ab}$ & $5.21 \mathrm{ab}$ \\
\hline 2.25 ton.ha ${ }^{-1}$ of fish waste +15 ton. ha $a^{-1}$ of cow manure & $90.02 \mathrm{a}$ & $7.52 \mathrm{a}$ & $7.84 \mathrm{a}$ \\
\hline
\end{tabular}

Remark: Numbers followed by the same letters in one colomn indicate no significant difference based on DMRT at $\alpha=5 \%$.

Table 6. N, P, K uptake in plant roots at the maximum vegetative phase (56 days after planting)

\begin{tabular}{|c|c|c|c|}
\hline \multirow{2}{*}{ Treatment } & \multicolumn{3}{|c|}{ plant root (mg per plant) } \\
\hline & $\mathrm{N}$ & $P$ & $\mathrm{~K}$ \\
\hline Control & $4.65 \mathrm{c}$ & $0.98 \mathrm{c}$ & $2.04 \mathrm{c}$ \\
\hline 1.5 ton.ha ${ }^{-1}$ of fish waste & $10.40 \mathrm{~b}$ & $1.56 \mathrm{~b}$ & $4.16 \mathrm{ab}$ \\
\hline 2.25 ton.ha h $^{-1}$ of fish waste & $10.84 \mathrm{~b}$ & $2.84 a b$ & $3.63 \mathrm{ab}$ \\
\hline 7 ton.ha ${ }^{-1}$ of cow manure & $12.79 \mathrm{~b}$ & $2.64 a b$ & $4.97 \mathrm{ab}$ \\
\hline 15 ton.ha-1 of cow manure & $11.40 \mathrm{~b}$ & $2.16 \mathrm{ab}$ & $2.74 b$ \\
\hline 1.5 ton.ha $a^{-1}$ of fish waste +7 ton.ha ${ }^{-1}$ of cow manure & $16.79 \mathrm{~b}$ & $1.54 \mathrm{~b}$ & $2.98 \mathrm{~b}$ \\
\hline 1.5 ton.ha-1 of fish waste +15 ton. ha $^{-1}$ of cow manure & $21.31 \mathrm{ab}$ & $2.36 \mathrm{ab}$ & $3.60 \mathrm{ab}$ \\
\hline 2.25 ton. ha $^{-1}$ of fish waste +7 ton.ha ${ }^{-1}$ of cow manure & $26.58 \mathrm{ab}$ & $3.52 \mathrm{a}$ & $5.28 \mathrm{a}$ \\
\hline 2.25 ton.ha ${ }^{-1}$ of fish waste +15 ton.ha $a^{-1}$ of cow manure & $34.12 \mathrm{a}$ & $4.63 \mathrm{a}$ & 5.35 a \\
\hline
\end{tabular}

Remark: Numbers followed by the same letters in one colomn indicate no significant difference based on DMRT at $\alpha=5 \%$.

of fish waste, but is not significantly different from the results by the application of 2.25 ton. ha $^{-1}$ of fish waste +7 ton. ha ${ }^{-1}$ of cow manure. The greater the dose of cow manure applied, the higher the availability of $\mathrm{N}$ nutrients in the soil and the higher the $\mathrm{N}$ uptake in rice plants. The increase in $\mathrm{N}$ nutrient uptake in plant shoot due to organic matter can increase the nitrogen according to $\mathrm{N}$ availability in the soil. Cow manure and salted fish waste function as soil amendment and nutrient suppliers in the soil, such as N (Setyamidjadja, 1986). Salted fish waste is also a good medium for the growth of decomposing bacteria (Marpaung, 2015). The decay process in salted fish can be caused by the activity of enzymes found in the fish body so that $\mathrm{N}$ elements are available to plants and can be absorbed by plants (Zahroh, 2015).
The analysis result on $\mathrm{N}$ and $\mathrm{K}$ uptake of roots rice at the maximum vegetative phase (Table 6) indicated that the application of salted fish waste and cow manure had a significant effect on $N, P$, and $\mathrm{K}$ uptake in the shoot and roots of rice plants. The application of 2.25 ton.ha $^{-1}$ of fish waste +15 ton.ha ${ }^{-1}$ of cow manure increased the $\mathrm{N}$ and $\mathrm{K}$ uptake in the roots of rice plants, compared with the treatment of 1.5 ton.ha ${ }^{-1}$ and 2.25 ton.ha ${ }^{-1}$ of fish waste. The application of fish waste containing $\mathrm{NaCl}$ that can increase soil salinity causes a decrease in plant growth. It occurs because of the osmotic effect of salt around the roots of plants so that leaf cells lose water and lose the volume content of cells (Cramer, 2002). Meanwhile, the application in small amount is inefficient because of its ability to increase soil pH, 
and nutrient availability becomes lower, evidenced by the application of 1.5 ton.ha ${ }^{-1}$ of fish waste treatment that has the lowest NPK nutrient uptake in the roots and shoot of rice plants.

Sufficient nutrients will certainly support plant growth and generate higher production. It is known that $\mathrm{N}, \mathrm{P}$, and $\mathrm{K}$ nutrients are the primary macro nutrients highly needed by plants more than other nutrients. In addition, an increase in NPK nutrient uptake in rice due to the application of salted fish waste and cow manure is assumed to becaused by the contribution of soil organic matter from organic fertilizers application, thereby improving the physical, chemical and biological properties of the soil. The effects of salted fish waste and cow manure on plants, both directly and indirectly, are encouraging plant growth, increasing production, and improving production quality as a result of improved plant nutrition (Leiwakabessy and Sutandi, 2004).

\section{CONCLUSIONS}

Based on the results of this study, it can be concluded that the application of 2.25 ton.ha ${ }^{-1}$ of fish waste +15 ton.ha ${ }^{-1}$ of cow manure significantly improved the chemical properties of peat soil, including the soil $\mathrm{pH}$, total $\mathrm{K}$, and $\mathrm{N}$ uptake. This research also showed that $\mathrm{N}, \mathrm{P}$, and $\mathrm{K}$ uptake in plants was the highest in the treatment of 2.25 ton.ha $^{-1}$ of fish waste +15 ton.ha ${ }^{-1}$ of cow manure and the lowest in the treatment of 1.5 ton.ha- ${ }^{-1}$ of fish waste treatment. Salted fish waste and optimally processed cow manure have a significant effect on encouraging plant growth, increasing production, and improving production quality as a result of improved plant nutrition.

\section{REFERENCES}

Agus, F. and I.G.M. Subiksa. 2008. Peatlands: Potential for agriculture and environmental aspects. $1^{\text {st }}$ ed., Bogor: Soil Research Center and World Agroforestry Center (ICRAF).

Balittanah. 2009. Analisis kimia tanah, tanaman, air, dan pupuk. http://balittanah.litbang.pertanian.go.id/ind/dokumentasi/buku/juknis\%20ki mia\%20edisi\%202/juknis_kimia2.pdf

Cramer G.R. 2002. Response of abscisic acid mutants of Arabidopsis to salinity. Funct. Plant Biol., 29: $561-567$

Istomo. 2006. Evaluation and adjustment of the silvicultural system of peat swamp forests, especially ramin species (Gonystylus bancanus (Miq.) Kurz.) In Indonesia. $1^{\text {st }}$ ed., Proceedings of the National Workshop on Alternative Policies in the Preservation and Use of Ramin.

Krueger, J.P., J.Leifeld, S.Glatzel, S.Szidat, and C. Alewell. 2015. Biogeochemical indicatorsof peatland degradation: A case study of a temperate bog in northern Germany. Bio-geosciences., 12: 28612871.

Leiwakabessy F.M. and A. Sutandi. 2004. Fertilizers and fertilizers. $2^{\text {nd }}$ ed., Bogor: Department of Land Faculty of Agriculture Bogor Agricultural University.

Miller, R.H. and R. L. Donahue. 1990. An introduction to soil and plantgrowth. $1^{\text {st }}$ ed. Englewood Cliffs, NJ. : Printice Hall Inc.

Ministry of Maritime Affairs and Fisheries. 2005. Utilization of fish waste as organic fertilizer raw materials. https://kkp.go.id/djpb.

Mokolobate, M.S. and R.J. Haynes, 2002. Increases in ph and soluble salts influence the effect that additions of organic residues have on concentrations of exchangeable and soil solution 
aluminium. European J. Soil Sci., 53:481-489.

Munns, R. and M. Tester., 2008. Mechanisms of salinity tolerance. Annu. Rev. Plant Biol., 59: 651-681.

Najiyati, S.; A. Asmana and I.N.N. Suryadiputra. 2005. Panduan pengelolaan lahan gambut untuk pertanian berkelanjutan. $1^{\text {st }}$ ed., Bogor: Wetlands Intl. Indonesia Prog. and Wildlife Habitat Canada.

Radjagukguk, B. 1997. Sustainable agriculture on environmentally friendly peatlands In Natural. Environmentally Friendly Peat Management. $2^{\text {nd }}$ ed., Jakarta: BPP Technology.

Radjagukguk, B. 2000. Changing the physical and chemical properties of peat soil due to peat land reclamation for agriculture. Journal of Soil and Environmental Sciences., 1: 1-15.

Ratmini, S. 2012. Characteristics and management of peat land for agricultural development. Suboptimal Land Journal., 12: 197-206.

Salisbury, F.B. and C.W. Ross. 1995. Plant physiology. $2^{\text {nd }}$ ed., Bandung: ITB.
Salsi, I. 2011. Characterization of peat with various ameliorant materials and their effects on physical and chemical properties to support the productivity of peatlands. Agrovigor Journal, 14: 42-50.

Sarief, E.S. 1986. Agricultural sciences. $8^{\text {th }}$ ed., Bandung: Library Buana.

Setyamidjaja, D. 1986. Fertilizers and fertilizers. $1^{\text {st }}$ ed., Jakarta: Simplex.

Surya, R.E. and Suryono. 2013. Effect of composting on the ratio of $\mathrm{C} / \mathrm{N}$ of animal manure and available NPK nutrient levels and soil cation exchange capacity. UNESA Journal of Chemistry, 2: 137-144.

Wong, M.T.F., S. Nortcliff, and R.S. Swift, 1998. Method for determining the acid ameliorating capacity of residue compost, urban waste compost, farm yard manure and peat applied to tropical soils. Communications in Soil Science and Plant Analysis., 29: 2927-2937. 